\title{
Effect of Foliar Application of Nano Chitosan NPK Fertilizer on the Chemical Composition of Wheat Grains
}

\author{
Heba Mahmoud Mohammad Abdel-Aziz , Mohammed Nagib Abdel-Ghany \\ Hasaneen and Aya Moheb Omer \\ Department of Botany, Faculty of Science, Mansoura University, Dakahlia, Egypt.
}

\begin{abstract}
N THIS paper we investigated the effect of foliar application of nano chitosan NPK fertilizer on the chemical composition of wheat grains. Foliar application of nanofertilizers showed a significant increase in total saccharide content of wheat grains grown on clay- sandy, clay and sandy soils. The magnitude of increase was most pronounced in the grains of nanofertilizered plants than in normal fertilized wheat plants, particularly at $10 \%$ nanofertilizer. As compared with control, treatment of wheat plants with increasing levels of either normal or nanofertilizer induced significant decrease in protein content and nitrogen content of the wheat grains. Treatment of wheat plants with nanofertilizers significantly increased the element content, especially potassium and phosphorus contents in the wheat grains. The magnitude of increase was most pronounced at clay-sandy soil, followed by clay soil and finally sandy soil. Further studies are required to understand the mechanisms by which nano fertilizers improve the quality of wheat grains.
\end{abstract}

Keywords: Nanofertilizer, Wheat, Nanochitosan, Carbohydrate, Protein, Elements.

\section{Introduction}

Nanotechnology had proved its place in agriculture and related industries (Froggett, 2009). The key focus areas for nanotechnology agricultural research are agricultural diagnostics, nanogenetic manipulation of agricultural crops, drug delivery, nanobiosensors, nanobiofarming, nanopesticides, nanoherbicides and controlled release of nanofertilizers and nanocomplexes (Agrawal \& Rathore, 2014). Nanofertilizers are used to supply nutrients to plants. They have nano-dimensions ranging from 30 to $40 \mathrm{~nm}$ and are able to hold numerous ions because of their high surface area and slowly release them in a timely manner to cope with crop demand. There are slow-release and super sorbent phosphatic and nitrogenous fertilizers (Lal, 2008). Nanofertilizers have unique features like increase in production, ultra-high absorption, increase in photosynthesis, and significant expansion in the leaves surface area (INIC, 2014).

Chitosan nanoparticles (nano chitosan) are one of the engineered nanomaterials and are natural materials with excellent physicochemical properties; further, they are environmentally friendly as well as bioactive (Agnihotri et al.,
2004). Such unique properties of the chitosan biopolymer can be enhanced by using it in the form of nanoparticles, as in this form, it can introduce different biological activities with altered physicochemical properties like surface area, size, cationic nature, etc. (Chandra et al., 2015). Chitosan nanoparticles are currently used to carry ions of fertilizers to be applied to plants. Foliar application of chitosan nanoparticles showed improvements of growth and yield of wheat plants especially at lower concentration $10 \%$ (Abdel-Aziz et al., 2016). Chitosan nanoparticles are easily absorbed by the epidermis of leaves translocated to stems which facilitated the uptake of active molecules and enhanced growth and productivity of several crop plants (Malerba \& Cerana, 2016). Van et al. (2013) showed that the foliar application of chitosan nanoparticles to coffee seedlings in the green house enhanced significantly the uptake of nitrogen content from 20 to $35 \%$, phosphorous content from 50 to $100 \%$, potassium content from 30 to $40 \%$, calcium (3.77\%) and magnesium (18.75\%) compared to the control. They reported that the optimal concentration of chitosan nanoparticles for nutrient uptake was $10 \mathrm{ppm}$; while higher concentration of chitosan nanoparticles reduced 
the nitrogen and mineral content of coffee leaves (Van et al., 2013).

The aim of the present study was to study the effect of foliar application of chitosan nano- sized NPK fertilizer at different concentrations $(10 \%$, $25 \%$ and $100 \%$ ) on the chemical composition of wheat grains grown on different soil types.

\section{Materials and Methods}

Preparation and characterization of nano chitosan NPK fertilizers

According to De Moura et al. (2008) and Hasaneen et al. (2014) the chitosan polymethacrylic acid (CS-PMAA) nanoparticles were prepared. Nitrogen, phosphorus and potassium were loaded on the CS-PMAA nanoparticles using the following concentrations 500, 60 and 400 ppm, respectively. All the results obtained were published in Hasaneen et al. (2014).

\section{Plant material and growth conditions}

Uniformly- sized lot of grains of pure strain wheat (Triticum aestivum L.) cv. Egypt 1 was kindly supplied by the Agriculture Research Center, Ministry of Agriculture, Giza, Egypt. Using tap water, the grains were washed and then planted in clay-sandy $(2: 1 \mathrm{v} / \mathrm{v})$, clay and sandy soils in pots $(30 \times 28 \times 26 \mathrm{~cm})$ in the botanical garden of the Faculty of Science at Mansoura University, Egypt, in the period from November 2012 to April 2013. The same set of experiment was repeated next season from November 2013 to April 2014 for confirmation of the provided results. All pots contained $8 \mathrm{~kg}$ of homogenous soil.

Treatment of wheat plants with bulk material (normal) or nanofertilizer were carried out after 21 days of the date of planting. By solution dropping method, the required concentration of aqueous NPK solution and NPK nanoparticle suspension were foliary sprayed. During the treatment, the pot surface was covered by plastic cover to prevent the applied material from entering into the soil system. Different fertilization treatments were applied three times at three weeks intervals. Tap water was used for irrigation, if required, to maintain the soil at the field capacity throughout the experiment. The following treatments were used: Control (C), foliar spray of normal NPK $10 \%$ (NPK 10), foliar spray of normal NPK 25\% (NPK 25), foliar spray of normal NPK 100\% (NPK 100), foliar spray of nano NPK 10\% (Nano 10), foliar spray of nano NPK 25\% (Nano 25) and foliar spray of nano NPK 100\% (Nano 100).
Samples representing the yielded grains of wheat were harvested after 96 days from the date of planting. The samples were taken in a way so as to include plants from those allotted for each treatment in 2 pots.

It should be mentioned that the results for analysis of the wide assay of metabolites of wheat grains yield obtained in the two experiments were remarkably close, thus only the mean values obtained from both of the two experiments will be presented in the corresponding tables presented in this paper.

\section{Estimation of total soluble sugars}

Total soluble sugars were extracted and determined using modification of procedure of Yemm \& Willis (1954). Sugars were extracted by overnight submersion of dry tissue in 10 $\mathrm{ml}$ of $80 \%(\mathrm{v} / \mathrm{v})$ ethanol at $25^{\circ} \mathrm{C}$ with periodic shaking. Total soluble sugars were analyzed by reacting $0.1 \mathrm{ml}$ of alcoholic extract with $3.0 \mathrm{ml}$ freshly prepared anthrone in a boiling water bath for $10 \mathrm{~min}$ followed by cooling and reading at wavelength $625 \mathrm{~nm}$.

\section{Estimation of polysaccharides}

Polysaccharides were estimated according to Thayumanavan \& Sadasivam (1984). Polysaccharide content (starch) was determined as mg glucose equivalents from the standard curve.

\section{Estimation of protein content}

The grains were homogenized in an ice bath and mixed with $2 \mathrm{ml}$ of $0.2 \mathrm{M}$ Tris- $\mathrm{HCl}$ buffer, $\mathrm{pH}$ 6.8. The mixture was then centrifuged at $19000 \mathrm{~g}$ for 20 minutes at $4{ }^{\circ} \mathrm{C}$. From 0.05 to $0.1 \mathrm{ml}$ of the extract was pipetted into test tubes and $5 \mathrm{ml}$ of protein reagent (Coomassie Brilliant Blue G-250) were added to the test tubes. The contents were mixed well and the absorbance was measured against a blank prepared from 0.05 to $0.1 \mathrm{ml}$ of the buffer in addition to $5 \mathrm{ml}$ of protein reagent at 595 $\mathrm{nm}$ using a spectrophotometer (Bradford, 1976).

\section{Estimation of Total nitrogen (TN)}

Total nitrogen was determined in the grains extract using the micro-Kjeldahl according to the method of Allen et al. (1986). The analysis involves a preliminary digestion to convert the organic nitrogen to ammonia, then distillation of the total ammonia into an acid absorbing solution and determination of the ammonia by an appropriate method.

\section{Estimation of phosphorus}

The methods adopted for extraction of 
phosphorus were essentially those described by Barker \& Mapson (1964). A known fresh weight of wheat grains was extracted with $5 \%$ trichloroacetic acid (TCA) in a mortar. The extract was then filtered and the filtrate was made up to volume and used for inorganic and total phosphorus analyses.

\section{Determination of inorganic phosphorus}

The method of Kuttner \& Lichtenstein (1932) as described by Humphries (1956) was adopted in the present investigation. Two $\mathrm{ml}$ of the trichloroacetic acid extract was mixed with $2.5 \mathrm{ml}$ of $10 \mathrm{~N} \mathrm{H}_{2} \mathrm{SO}_{4}$ and $1 \mathrm{ml}$ ammonium molybdate solution in a $100 \mathrm{ml}$ measuring cylinder and the volume completed to $45 \mathrm{ml}$. The mixture was well shaken and $1 \mathrm{ml}$ of stannous chloride solution was added. This was followed by immediate shaking, making up to volume and mixing the contents thoroughly. The samples were allowed to stand for $20 \mathrm{~min}$ before reading the optical densities of the colour developed at $710 \mathrm{~nm}$ using spectrophotometer. The amounts of phosphate in the extracts were calculated from a standard curve prepared with known amounts of $\mathrm{KH}_{2} \mathrm{PO}_{4}$.

\section{Estimation of total phosphorus}

Two $\mathrm{ml}$ of the trichloroacetic acid extract was transferred into a digestion flask followed by 2.5 $\mathrm{ml}$ of $10 \mathrm{~N} \mathrm{H}_{2} \mathrm{SO}_{4}$ and the mixture was incinerated on a micro-heater for $25 \mathrm{~min}$. The flask was cooled and the mixture was quantitatively transferred to a measuring cylinder and the procedure adopted for inorganic phosphorus was here followed exactly to estimate the total phosphorus. The blank using distilled water instead of extract was always prepared simultaneously with each set of determinations. The total acid soluble organic phosphorus was obtained by subtracting the inorganic phosphorus from the total phosphorus.

\section{Estimation of potassium}

Potassium content was measured according to the method described by Motsara \& Roy (2008). Oven-dried wheat grains were ground into a fine powder. For the wet digestion, $10 \mathrm{ml}$ of conc. $\mathrm{HNO}_{3}$ were added to a known weight of each dry ground sample and the mixture was heated at 80 $90^{\circ} \mathrm{C}$ on a hot plate in a fuming hood. Heating was continued until the production of red $\mathrm{NO}_{2}$ fumes ceased. The content was further heated until the volume reduced to 3-4 $\mathrm{ml}$ and became colourless. After cooling the content, the volume was made up with distilled water and filtered through Whatman No. 1 filter paper. This solution was used for nutrient estimation. Potassium content was analyzed by atomic emission spectrophotometer (ICAP- 757V, Nippon Jarrell Ash, Kyoto, Japan).

\section{Statistical analysis}

Experimental data were subjected to one-way analysis of variance (ANOVA) with Post Hoc L.S.D. (least significant difference) test. A $* P$ value $<0.05$ was accepted statistically significant. Statistical analysis was performed with statistical package for social science for windows (SPSS, version 13.0, 2004, Chicago, IL, USA).

\section{Results}

Changes in carbohydrate contents of yielded grains

The changes in the amounts of carbohydrates in the wheat grains of the control, as well as of the differently treated wheat plants are presented in Table 1. All the variously fertilized wheat plants grown on clay-sandy, clay and sandy soils showed significant decrease in the total soluble sugar content of the yielded grains. The magnitude of decrease was most pronounced in all treated plants grown in sandy soils. As compared with control values, polysaccharide content of normal and nanofertilized wheat plants grown on clay, claysandy and sandy soils showed significant increases. The magnitude of increase was most pronounced in Nano 10 treated plants. The following sequence of treatments (Nano $10>$ Nano $25>$ Nano 100 $>$ NPK $100>$ NPK 25> NPK 10> control) was displayed with respect to polysaccharide content of yielded grains. Clay-sandy soil was the best soil for cultivation of wheat plants treated with nanofertilizers. Thus, clay-sandy soil $>$ clay soil $>$ sandy soil was displayed with respect to total carbohydrates content of yielded grains.

\section{Changes in protein content of yielded grains}

Examination of Table 2 revealed that protein content of the wheat grains from all treatments was lower than that observed in control. Normal and nanofertilized wheat plants grown on clay, clay-sandy and sandy soils showed protein content values lower than that detected in control plants, the magnitude of decrease was most pronounced in sandy soil. The following sequence of treatments (control $>$ NPK $10>$ NPK $25>$ NPK $100>$ Nano $100>$ Nano $25>$ Nano 10) was displayed with respect to protein content.

Changes in element content (NPK) of yielded grains The data presented in Table 3 revealed 
TABLE 1. The effect of bulk material NPK fertilizer and nano-engineered composite NPK fertilizer on total soluble sugar content, polysaccharide content and total saccharides content of yielded grains of wheat plants grown on clay, clay-sandy and sandy soils.

\begin{tabular}{|c|c|c|c|c|c|c|c|c|c|}
\hline \multirow{2}{*}{ Preatments } & \multicolumn{3}{|c|}{$\begin{array}{c}\text { Total soluble sugars } \\
\text { (mg glucose/g dry weight) }\end{array}$} & \multicolumn{3}{|c|}{$\begin{array}{c}\text { Polysaccharides } \\
\text { (mg glucose equivalent / g } \\
\text { dry weight) } \\
\end{array}$} & \multicolumn{3}{|c|}{$\begin{array}{c}\text { Total saccharides } \\
\text { (mg glucose equivalent / } \mathrm{g} \\
\text { dry weight) }\end{array}$} \\
\hline & $\begin{array}{l}\text { Clay- } \\
\text { sandy }\end{array}$ & Clay & Sandy & $\begin{array}{l}\text { Clay- } \\
\text { sandy }\end{array}$ & Clay & Sandy & $\begin{array}{l}\text { Clay- } \\
\text { sandy }\end{array}$ & Clay & Sandy \\
\hline Control & 29.19 & 27.71 & 24.39 & 666.84 & 652.82 & 636.37 & 696.03 & 680.53 & 660.76 \\
\hline NPK 10 & $26.68^{*}$ & $25.10^{*}$ & $23.63^{*}$ & $673.14^{*}$ & $660.90 *$ & $678.11^{*}$ & $699.82 *$ & $686.00 *$ & $701.74 *$ \\
\hline NPK 25 & $25.43^{*}$ & $24.63^{*}$ & $22.75^{*}$ & $698.68^{*}$ & $681.26^{*}$ & $691.19^{*}$ & $724.11 *$ & $705.89 *$ & $713.94 *$ \\
\hline NPK100 & $23.40^{*}$ & $22.35^{*}$ & $21.64^{*}$ & $726.70 *$ & $702.68^{*}$ & $700.66^{*}$ & $750.10^{*}$ & $725.03 *$ & 722.30 * \\
\hline Nano10 & $20.12^{*}$ & $19.06^{*}$ & $19.47^{*}$ & $798.15^{*}$ & $746.90 *$ & $751.80 *$ & $818.27^{*}$ & $765.96^{*}$ & $771.27^{*}$ \\
\hline Nano 25 & $19.04 *$ & $18.82 *$ & $18.66^{*}$ & $773.07 *$ & $730.51 *$ & $726.09^{*}$ & $792.11 *$ & $749.33 *$ & $744.75^{*}$ \\
\hline Nano100 & $18.41^{*}$ & $17.27^{*}$ & $17.01^{*}$ & $756.75^{*}$ & $718.30 *$ & $725.17 *$ & $775.16^{*}$ & $735.57 *$ & $742.18^{*}$ \\
\hline
\end{tabular}

* Mean values are significantly different from control at $\mathrm{P} \leq 0.05$.

TABLE 2. The effect of bulk material NPK fertilizer and nano-engineered composite NPK fertilizer on protein content of yielded grains of wheat plants grown on clay, clay-sandy and sandy soils.

\begin{tabular}{|c|c|c|c|}
\hline \multirow[b]{2}{*}{ Treatments } & \multicolumn{3}{|c|}{$\begin{array}{c}\text { Protein } \\
(\mathrm{mg} / \mathrm{g} \text { dry weight) }\end{array}$} \\
\hline & Clay-sandy & Clay & Sandy \\
\hline Control & 86.00 & 83.20 & 82.32 \\
\hline NPK 10 & $83.60 *$ & $80.40^{*}$ & $80.04 *$ \\
\hline NPK 25 & $82.28 *$ & $79.44 *$ & $78.32 *$ \\
\hline NPK100 & $80.52 *$ & $78.92 *$ & $77.72 *$ \\
\hline Nano10 & $73.60^{*}$ & $72.68^{*}$ & $71.08^{*}$ \\
\hline Nano 25 & $76.32 *$ & $75.80^{*}$ & $75.62 *$ \\
\hline Nano100 & $79.24 *$ & $78.80^{*}$ & $76.63^{*}$ \\
\hline
\end{tabular}

* Mean values are significantly different from control at $\mathrm{P} \leq 0.05$.

that, in relation to control grains yield content, administration of normal and nano-NPK fertilizers induced significant decrease in total nitrogen element. The magnitude of decrease was most pronounced in Nano 10 grains of wheat plants grown on sandy soil followed by clay and claysandy soils. On the other hand, $\mathrm{K}^{+}$element content showed increased levels as compared with control. The magnitude of increase was most pronounced in Nano 10 fertilizered grains of wheat plants grown on clay-sandy soil.

With respect to total phosphorus content (Table 4), a variable increase was observed in grains yielded from wheat plants treated with either normal or nanofertilizers, grown on clay, clay-sandy and sandy soils, as compared with control. Except for the observed decrease in inorganic phosphorus content of yielded grains of wheat plants treated with normal and nanofertilizers and grown on clay, clay-sandy and sandy soils, the other differently treated plants showed significant increase in organic phosphorus content, above the control levels (Table 4). The following sequence of treatments (Nano 10 $>$ Nano $25>$ Nano $100>$ NPK $100>$ NPK $25>$ NPK $10>$ control) was displayed with respect to organic and total phosphorus contents of yielded grains of wheat plants grown on clay, clay-sandy and sandy soils. 
TABLE 3. The effect of bulk material NPK fertilizer and nano-engineered composite NPK fertilizer on total nitrogen element and potassium element contents of yielded grains of wheat plants grown on clay, claysandy and sandy soils.

\begin{tabular}{lcccccc} 
Treatments & \multicolumn{3}{c}{$\begin{array}{c}\text { Total N } \\
\text { (mg/g dry weight) }\end{array}$} & \multicolumn{2}{c}{$\begin{array}{c}\mathbf{K}^{+} \\
\text {(mg/g dry weight) }\end{array}$} \\
\cline { 2 - 7 } Control & Clay-sandy & Clay & Sandy & Clay-sandy & Clay & Sandy \\
NPK 10 & 24.60 & 23.28 & 22.21 & 1.33 & 1.20 & 1.18 \\
NPK 25 & $23.37^{*}$ & $22.18^{*}$ & $22.08^{*}$ & $2.01^{*}$ & $1.64^{*}$ & $1.52^{*}$ \\
NPK100 & $23.08^{*}$ & $21.98^{*}$ & $21.66^{*}$ & $2.21^{*}$ & $1.77^{*}$ & $1.62^{*}$ \\
Nano10 & $21.77^{*}$ & $21.09^{*}$ & $20.99^{*}$ & $2.41^{*}$ & $1.93^{*}$ & $1.68^{*}$ \\
Nano 25 & $17.45^{*}$ & $17.04^{*}$ & $16.93^{*}$ & $3.01^{*}$ & $2.82^{*}$ & $1.90^{*}$ \\
Nano100 & $18.75^{*}$ & $18.06^{*}$ & $17.95^{*}$ & $2.86^{*}$ & $2.57^{*}$ & $1.80^{*}$ \\
\hline
\end{tabular}

* Mean values are significantly different from control at $\mathrm{P} \leq 0.05$.

TABLE 4. The effect of bulk material NPK fertilizer and nano-engineered composite NPK fertilizer on inorganic, organic and total phosphorus contents of yielded grains of wheat plants grown on clay, clay-sandy and sandy soil.

\begin{tabular}{|c|c|c|c|c|c|c|c|c|c|}
\hline \multirow[b]{2}{*}{ Treatments } & \multicolumn{3}{|c|}{$\begin{array}{c}\text { Inorganic } P \\
\text { (mg/g fresh weight) }\end{array}$} & \multicolumn{3}{|c|}{$\begin{array}{c}\text { Organic } P \\
\text { (mg/g fresh weight) }\end{array}$} & \multicolumn{3}{|c|}{$\begin{array}{c}\text { Total } P \\
\text { (mg/g fresh weight) }\end{array}$} \\
\hline & $\begin{array}{l}\text { Clay- } \\
\text { sandy }\end{array}$ & Clay & Sandy & $\begin{array}{l}\text { Clay- } \\
\text { sandy }\end{array}$ & Clay & Sandy & $\begin{array}{l}\text { Clay- } \\
\text { sandy }\end{array}$ & Clay & Sandy \\
\hline Control & 0.072 & 0.071 & 0.069 & 0.223 & 0.205 & 0.143 & 0.295 & 0.276 & 0.212 \\
\hline NPK 10 & 0.070 & 0.069 & 0.066 & 0.229 & 0.220 & 0.154 & 0.299 & 0.289 & 0.220 \\
\hline NPK 25 & 0.069 & 0.066 & 0.062 & 0.231 & 0.226 & 0.189 & 0.300 & 0.292 & 0.251 \\
\hline NPK100 & 0.065 & 0.063 & 0.060 & 0.240 & 0.230 & 0.185 & 0.305 & 0.293 & 0.245 \\
\hline Nano10 & 0.057 & 0.052 & 0.046 & $0.284 *$ & $0.262 *$ & $0.240 *$ & 0.341 & 0.314 & $0.286^{*}$ \\
\hline Nano 25 & 0.060 & 0.056 & 0.049 & 0.262 & 0.250 & $0.229 *$ & 0.322 & 0.306 & $0.278 *$ \\
\hline Nano100 & 0.063 & 0.061 & 0.051 & 0.248 & 0.237 & $0.220^{*}$ & 0.311 & 0.298 & $0.271 *$ \\
\hline
\end{tabular}

* Mean values are significantly different from control at $\mathrm{P} \leq 0.05$.

\section{Discussion}

Nowadays, application of fertilizers containing NPK is vital for the development of crop production and plays important roles in food safety. The importance of these NPK fertilizers lies in their role to supply the necessary nutrients for plant growth (El-Diwani et al., 2013). When a nano-engineered composite which consists of $\mathrm{N}, \mathrm{P}$, $\mathrm{K}$, micronutrients, mannose and amino acids was applied to grain crops, it appeared to enhance the uptake and use of nutrients (Jinghua, 2004).

The present obtained results, showed that treatments of wheat plants with bulk material and chitosan NPK nanoparticles, at increasing concentrations throughout the entire period of experiment, induced varied significant increases in polysaccharides content of wheat grains in the plants grown in clay-sandy, clay and sandy soils, accompanied by significant decrease in total soluble sugars and protein contents in wheat grains of plants grown on clay, clay-sandy and sandy soils (Tables 1 and 2). To substantiate the above mentioned results, yielded grains are among the organs affected by nanoparticles and are most sensitive. Some research suggested that the application of nanofertilizer decreased the protein content and increased the fat content of wheat plants (Liu et al., 2008). It has been shown that engineered nanoparticles induced alterations in proteins in plants, but how this works is not yet clear (Rico et al., 2013). Further work is needed in order to understand the mechanism by which nanofertilizers modify proteins in the grain. It is supposed that nanofertilizers alter gene expression for protein synthesis during grain development 
similar to those observed in rice under drought conditions (Mushtaq et al., 2008).

The present results concerning the effect of engineered nanoparticles on carbohydrate and protein contents of the yielded grains of wheat plants, can be explained on the basis of modification in polysaccharide and soluble sugar contents of chitosan-NPK nanoparticles treated wheat plants as previously reported by Krishnaraj et al. (2012), Chai et al. (2013) and Mirzajani et al. (2013). In case of the present study, foliar application of chitosan nanoparticles increased the amount of polysaccharide content and decreased total soluble sugars in the harvested grains of wheat plants, which is in contrast to the conclusion of Rico et al. (2013) who reported that cerium oxide nanoparticles did not change the carbohydrate content of rice grains.

The mechanism of protein and carbohydrate modification by nanoengineered NPK nanoparticles in wheat grains has got to be elucidated. Similar studies revealed that nickel nanoparticles reduced carbohydrate level in rice root due to disturbance in the conversion of starch into sucrose (Moya et al., 1993), whereas cadmium stress led to dramatic perturbations in starch and sugar synthesis in rice roots and shoots (Verma \& Dubey, 2001). Another study revealed that drought affected the carbohydrate metabolic process involved in starch biosynthesis in developing rice grains (Mushtaq et al., 2008).

There was also interaction between chitosan NPK nanoparticles and soil types on wheat grains carbohydrate and protein contents (Tables 1 and 2). Application of $10 \%$ nanoparticles solution produced the highest total carbohydrate content as well as, $\mathrm{P}$ and $\mathrm{K}$ contents, but these parameters decreased at the higher concentration $(100 \%)$ of nanosolution. Similar results were obtained by Ghafari \& Razmjoo (2013).

The present results suggest that application of $10 \%$ nano NPK fertilizer was more effective than other treatments that was because below $100 \%$ chitosan nanoparticles perhaps made NPK more efficient and dissolved in water more effectively thus increased their uptake and activities resulting in improvement of grain wheat quality (Liscano et al., 2000; Joseph \& Morrison, 2006; Liu et al., 2010 and Ghafari \& Razmjoo, 2013).

In support of the present conclusion, Salama (2012) reported that for $60 \mathrm{ppm}$ Ag nanoparticles treatment, the carbohydrate content of Phaseolus vulgaris showed $57 \%$ increase and $62 \%$ increase in Zea mays plants over control. At concentrations 80 and $100 \mathrm{ppm}, \mathrm{Ag}$ nanoparticles treatment caused significant reduction in carbohydrate $(19 \%$ and $18 \%$ for common bean as well as $28 \%, 31 \%$ for corn plant, respectively).

Tables 3 and 4 showed the N, P and K contents in which there was a decrease in contents of inorganic phosphorus and total nitrogen contents in grains of wheat plants treated with normal NPK and nano-NPK fertilizers grown on either clay, clay-sandy and sandy soils, and an increase in the contents of potassium, organic phosphorus and total phosphorus.

The increase in $\mathrm{K}$ in rice grains treated with cerium oxide nanoparticles was reported by Rico et al. (2013) compared to NPK chemical fertilizers. The application of slow/controlled release fertilizer coated by nano-materials was reported to improve grain yield with significant increase in protein content and decrease in soluble sugar content in wheat, compared with NPK chemical fertilizer (Qiang et al., 2008).

The present study suggested that NPK fertilizer in the nanoscale form is absorbed by wheat plants to a large extent unlike bulk NPK fertilizer. These particles proved effective in enhancing plant growth, development and yield. A lower dose of foliar application is proved to be significantly productive (Prasad et al., 2012). The post-harvest grain samples analysis revealed a significant increase in $\mathrm{P}$ and $\mathrm{K}$ content. The promotive effects of nanosclae NPK fertilizers at cellular level has to be understood by further in depth investigations.

The present results concerning phosphorus content of grains yielded from wheat plants treated with either normal NPK or nanoscale NPK on clay, clay-sandy and sandy soils are in conformity with the findings of Setia \& Sharma (2007) and Vig et al. (2000). Patil et al. (1995) also reported that the applied phosphorus was the most important for the wheat yield.

\section{Conclusion}

Nano chitosan-NPK fertilizers could be used to improve the chemical composition of wheat grains (accumulation of carbohydrates). To our knowledge, the least concentration (Nano 10) was the best to obtain better wheat grains and the best type of soil was clay-sandy soil. The mechanism by which nanochitosan fertilizer improves wheat grain quality should be further elucidated with special emphasis on human safety of such application. 


\section{References}

Abdel-Aziz, H.M.M., Hassaneen, M.N.A. and Omer, A.M. (2016) Nano chitosan-NPK fertilizer enhances the growth and productivity of wheat plants grown in sandy soil. Spanish Journal of Agricultural Research, 14, 1-9.

Agnihotri, S.A., Mallikarjuna, N.N. and Aminabhavi, T.M. (2004) Recent advances on chitosan based micro- and nanoparticles in drug delivery. Journal of Controlled Release, 100, 5-28.

Agrawal, S. and Rathore, P. (2014) Nanotechnology pros and cons to agriculture: A review. International Journal of Current Microbiology and Applied Sciences, 3, 43-55.

Allen, S.E., Grimshaw, H.M., Parkinson, J.A., Quarmby, C. and Roberts, J.D. (1986) Chemical analysis. In: "Methods in Plant Ecology", Chapman, S.B. (Ed.), pp. 411-466. Blackwell Science Publishing, Oxford.

Barker, J. and Mapson, L.W. (1964) Studies in the respiratory and carbohydrate metabolism of plant tissue. XV. Effect of certain enzymic poisons on respiration, sugar and ascorbic acid of detached leaves. Journal of Experimental Botany, 15, 272283.

Bradford, M.M. (1976) A rapid and sensitive for the quantitation of microgram quantitites of protein utilizing the principle of protein-dye binding. Analytical Biochemistry, 72, 248-254.

Chai, M., Shi, F., Li, R., Liu, L., Liu, Y. and Liu, F. (2013) Interactive effects of cadmium and carbon nanotubes on the growth and metal accumulation in a halophyte Spartina alterniflora (Poaceae). Plant Growth Regulation, 71, 171-179.

Chandra, S., Chakraborty, N., Dasgupta, A., Sarkar, J., Panda, K. and Acharya, K. (2015) Chitosan nanoparticles: A positive modulator of innate immune responses in plants. Scientific Reports, 5, 13 pages, doi: 10.1038/srep15195

DeMoura, M.R., Aouda, F.A. and Mattoso, L.H.C. (2008) Preparation of chitosan nanoparticles using methacrylic acid. Journal of Colloid and Interface Science, 321, 477-483.

El-Diwani, G., Motawie, N., Shaarawy, H.H. and Shalaby, M.S. (2013) Nitrogen slow release biodegradable polymer based on oxidized starch prepared via electro generated mixed oxidants. Journal of Applied Sciences Research, 9, 1931-1939.

Froggett, S. (2009) Nanotechnology and agricultural trade. Proceedings of OECD Conference on the potential environmental benefits of nanotechnology: Fostering safe innovation-led growth, USA. Also at website https://www.oecd.org/science/ nanosafety/44029039.pdf.

Ghafari, H. and Razmjoo, J. (2013) Effect of foliar application of nano-iron oxidase, iron chelate and iron sulphate rates on yield and quality of wheat. International Journal of Agronomy and Plant Production, 4, 2997-3003.

Hasaneen, M.N.A., Abdel-Aziz, H.M.M., El-Bialy, D.M.A. and Omer, A.M. (2014) Preparation of chitosan nanoparticles for loading with NPK. African Journal of Biotechnology, 13, 3158-3164.

Humphries, E.C. (1956) Mineral components and ash analysis. In: "Modern Methods of Plant Analysis I', Peach, K. and Tracey, M.V. (Ed.), pp. 468-502, Verlag, Berlin-Göttingen-Heidelberg.

INIC (2014) Iran Nanotechnology Initiative Council. First nano-organic iron chelated fertilizer invented in Iran. http://www.iranreview. org/content/ Documents/Iranians_Researchers_Produce_Nano_ Organic_Fertilizer.htm.

Jinghua, G. (2004) Synchrotron radiation, soft X-ray spectroscopy and nano-materials. Journal of Nanotechnology, 1,193-225.

Joseph, T. and Morrison, M. (2006) Nanotechnology in Agriculture and Food. A Nanoforum report, Institute of Nanotechnoloy http: //www. nanoforum. org/ dateien/ temp/ nanotechnology $\% 20$ in $\% 20$ agriculture $\% 20$ and $\% 20$ food.pdf.

Krishnaraj, C., Jagan, E.G., Ramachandran, R., Abirami, S.M., Mohan, N. and Kalaichelvan, P.T. (2012) Effect of biologically synthesized silver nanoparticles on Bacopa monnieri (Linn.) Wettest plant metabolism. Process Biochemistry, 47, 651-658.

Kuttner, T. and Lichtenstein, L. (1932) Microcolorimetric studies. III. Estimation of organically bound phosphorus. A system of analysis of phosphorus compounds in blood. Journal of Biological Chemistry, 95, 661-670.

Lal, R. (2008) Soils and India's food security. Journal of the Indian Society of Soil Science, 56, 129-138.

Liscano, J.F., Wilson, C.E., Norman, R.J. and Slaton, N.A. (2000) Zinc availability to rice from seven granular fertilizers. Research Bulletin - Arkansas Agricultural Experiment Station, 963, 1-31.

Liu, J., Zhang, Y.D. and Zhang, Z.M. (2008) Study 
on application of nanometer biotechnology on the yield and quality of winter wheat. Journal of Anhui Agricultural Sciences, 36, 15578-15580.

Liu, X.M., Zhang, F.D., Zhang, S.Q., He, X.S., Fang, R., Feng, Z. and Wang, Y. (2010) Effects of nanoferric oxide on the growth and nutrients absorption of peanut. Plant Nutrition and Fertilizer Science, 11,14-18.

Malerba, M. and Cerana, R. (2016) Chitosan effects on plant systems. International Journal of Molecular Sciences, 17, 996.

Mirzajani, F., Askari, H., Hamzelou, S., Farzaneh, M. and Ghassempour, A. (2013) Effect of silver nanoparticles on Oryza sativa L. and its rhizosphere bacteria. Ecotoxicology and Environmental Safety, 88, 48-54.

Motsara, M.R. and Roy, R.N.(2008) “GuidetoLaboratory Establishment for Plant Nutrient Analysis", pp. 8090, Food and Agriculture Organization of the United Nations, Rome.

Moya, J.L., Ros, R. and Picazo, I. (1993) Influence of calcium and nickel on growth, net photosynthesis and carbohydrate distribution in rice plants. Photosynthesis Research, 36, 75-80.

Mushtaq, R., Katiyar, S. and Bennett, J. (2008) Proteomic analysis of drought stress-responsive proteins in rice endosperm affecting grain quality. Journal of Crop Science and Biotechnology, 11, 227-232.

Patil, S.K., Pal, A.R. and Katre, R.K. (1995) Field evaluation of $\mathrm{P}$ soil tests and the availability of $\mathrm{P}$ to wheat in a vertisol of Chhattisgarh, M. P., Ind. International Journal of Tropical Agriculture, 13,8187.

Prasad, T.N.V.K.V., Sudhakar, P., Sreenivasulu, Y., Latha, P., Munaswamy, V., Raja Reddy, K., Sreeprasad, T.S., Sajanlal, P.R. and Pradeep, T. (2012) Effect of nanoscale zinc oxide particles on the germination, growth and yield of peanut. Journal of Plant Nutrition, 35, 905-927.
Qiang, X., Fu-dao, Z., Yu-jun, W., Jian-feng, Z. and Shuqing, Z. (2008) Effects of slow/controlled release fertilizers felted and coated by nano-materials on nitrogen recovery and loss of crops. Plant Nutrition and Fertilizer Science, 14, 951-955.

Rico, C.M., Morales, M.I., Barrios, A.C., McCreary, R., Hong, J., Wen-Yee, L., Nunez, J., Peralta-Videa, J.R. and Gardea-Torresdey, J.L. (2013) Effect of cerium oxide nanoparticles on the quality of rice (Oryza sativa L.) grains. Journal of Agricultural and Food Chemistry, 61, 11278-11285.

Salama, H.M.H. (2012) Effects of silver nanoparticles in some crop plants, Common bean (Phaseolus vulgaris L.) and corn (Zea mays L.). International Research Journal of Biotechnology, 3, 190-197.

Setia, R.K. and Sharma, K.N. (2007) Dynamics of forms of inorganic phosphorus during wheat growth in a continuous maize-wheat cropping system. Journal of Indian Society of Soil Science, 55,139-146.

Thayumanavan, B. and Sadasivam, S. (1984) Physiochemical basis for the preferential uses of certain rice varieties. Plant Food, Human Nutrition, 34, 253-259.

Van, N.S., Minh, D.H. and Anh, N.D. (2013) Study on chitosan nanoparticles on biophysical characteristics and growth of Robusta coffee in green house. Biocatalysis and Agricultural Biotechnology, 2, 289-294.

Verma, S. and Dubey, R.S. (2001) Effect of cadmium on soluble sugars and enzymes of their metabolism in rice. Biologia Plantarum, 44, 117-123.

Vig, A.C., Yash-Pal, Saroa, G.S. and Bahl, G.S. (2000) Forms of $\mathrm{P}$ and efficacy of different soil tests for $\mathrm{P}$ extractability in calcareous soils. Journal of Indian Society of Soil Science, 48, 527-532.

Yemm, E.W. and Willis, A.J. (1954) The estimation of carbohydrates by anthrone. Journal of Biochemistry, $\mathbf{5 7}, 508-514$

(Received 14 / $11 / 2017$ accepted 2/1/2018) 
تأثير استخدام الرش الورقى بسماد النانو كيتوزان المحمل بالنيتروجين و الفوسفور و

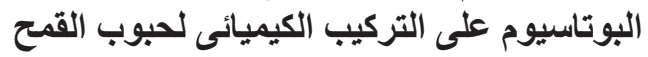

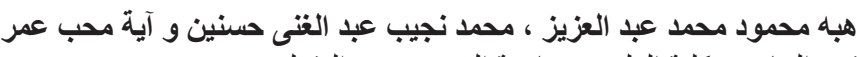

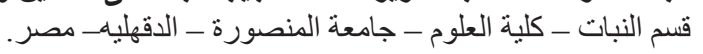

\begin{abstract}
إن استخدام التكنولوجيا النانوية في الممارسات الزر اعية اكتسب المزيد من الاهتمام البحثى فى الآونة الأخيرة.

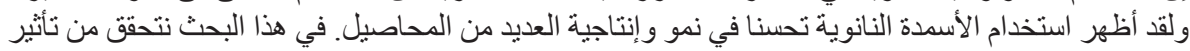

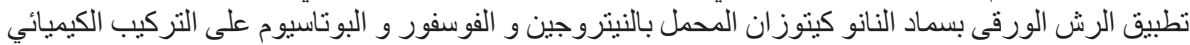

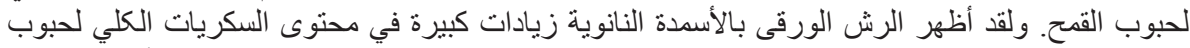

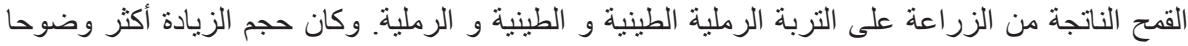

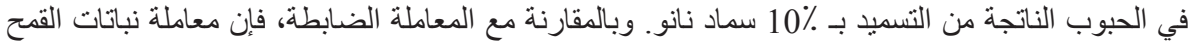

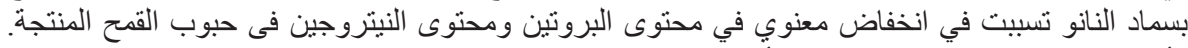

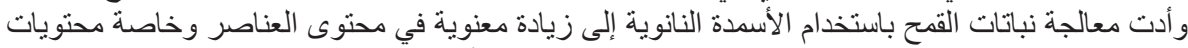

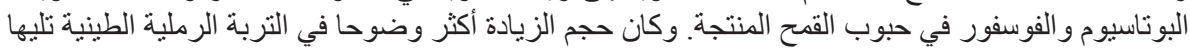

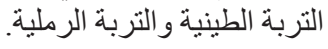

